\title{
THE HEAVENLY COW RUPAN AND THE FESTIVAL OF CEREMONIAL TORTURE GAI- GOHERI: MYTH, RITUALS AND SACRIFICE AMONG THE PEOPLE OF THE BHIL TRIBE OF WESTERN INDIA
}

\author{
Sarita Sahay
}

\begin{abstract}
Gai-Goheri, the festival of ceremonial torture, is a popular ritual among the people of the Bhil tribe of Western India. Beliefs and myths of this festival play an important role in forming a series of rituals, which include not only the buttock-burning of the cattle but also their decorations and worshipping. The ritual, in which the villagers, while in religious mood, prostrate before hundreds of running cattle and get seriously hurt, is the climax of the festival. Villagers then inhale the smoke of burning dhup (perfumed sawdust), dance and drink liquor in a state of trance.

This article makes a serious attempt to analyse the festival of ceremonial torture, as well as the associated rituals, along with the related mythological story of the cow named Rupan, which has presented a pragmatic charter of the primitive faith, vouching for the efficacies of the festival. The socio-economic system of the tribe has also helped in making the entire celebration amply adaptable even today.
\end{abstract}

Key words: Bhil, blood sacrifice, cow-worship, festival, myth, ritual, torture, trance

\section{INTRODUCTION}

Myths, rituals, sacrifices and festivals all play a different role in the religious life of a human being. Each and every religion contains at least two elements, Ritual and Mythology. Both, what he does i.e. his Ritual and what he thinks i.e. his Mythology, are alike informed and vivified by what he feels, what he desires (Harrison 1963). Myths and rituals are symbolic statements and actions through which religion finds expression. Myths express, enhance, and codify belief; safeguard and enforce morality and vouch for the efficiency of ritual. They present a pragmatic charter of primitive faith and moral wisdom (Mali- 
nowski 1954). Rituals insure stability and adaptability for society. They also act as the sources of social control both for the individual as well as for the community. Through sacrifice a devotee tries to establish communication between him and the supernatural power through sharing and offering the phenomenon. Festivals are the sacred times providing people with an opportunity to enter a sacred realm and leave the profane realm of their daily living. Thus, festivals are important for the psychological and emotional health of human beings, and facilitate community feelings within a society.

This article analyses rituals, myth and sacrifices made by the people while they celebrate the festival named Gai-Goheri. Villagers celebrate this festival to make them all free from anxieties of the future uncertainty regarding the safety of their cattle, i.e. their main economic asset.

\section{MYTHS, RITUALS, SACRIFICES, AND FESTIVAL: MEANINGS AND IMPORTANCE}

\section{Myths}

The Greek term 'muthos', from which the word 'myth' comes, is derived from the Indo-European root 'meudh' or 'mudh', which means to 'reflect', 'to think over', or 'to consider' (Graeve et al. 2002: 120-125). For the Greeks, 'muthos' had meant 'a tale', or 'something uttered', 'a story' or 'the plot of a play' (Kirk 1970).

Myth can be defined as an anonymous traditional story typically involving gods, goddesses, heroes, heroines and other real and fantastic creatures whose adventures, taking place in the remote times, represent significant aspects of human experience. Myths are orally passed from one generation to the next and are believed to be literally true by the culture that produced them. These are preserved and transmitted over time because they are seen as meaningful for the society that transmits them. (Bolle 1981: 797-800; Mercatante 1988; Platzner \& Harris 2004). Myths are symbolic statements about the meaning and purpose of life in this world (Roberts 1984). Thus, myths symbolize human experience and embody the spiritual values of a culture. Every society preserves its myths, as the beliefs and the worldview, found within them, are crucial to the survival of that culture (Rosenberg 1999). Myth is not the consequence of historical viscosity (Belmont 1996: 308-309). They recount events that happened before history began, taking place in principio, that is in the beginning', a moment of sacred time (Eliade 1961: 59). 
Myths differ considerably from other literary genres such as etiological tales, fairy tales, fables, sagas etc. Etiological tales explain the origin of a custom, or a peculiar, human or divine condition, whereas myths indicate their foundation or validity. Fairy tales and folktales, too, tell of extraordinary beings and events, but the time frame is that of man's ordinary experience. Fables are fictional stories, but myths are symbolic statements about great religious truths. Sagas, epics and legends are narratives with a degree of truth, the difference lies in the time frame - sagas and epics are related to time, the bygone time of a people, whether historical or non-historical. A legend always has a historical nucleus, being based on an event of profane history. However, myths deal with meta-historical events (Sløk 2003: 124-129). According to their subject matters, myths can be classified into several types. The more important among them are cosmological, theological and anthropological ones, paradise myths, myths of fall and flood, and eschatological or stereological myths (Calhoun 2002; Dhavamony 1973). Myths are important because of their existential function for man. Insisting on this, Malinowski states that the primary function of a myth is neither to explain nor to recount past historical events, but to lay down the effective precedent of a glorified past for repetitive actions in the present (Malinowski 1967). The function of myths is to express the very being and structure of society and the ideology under which it lives, to upload the value and ideas, and to justify the traditions, which are the cementing force within a society (Dumézil 1970).

Myths also explain natural, social, cultural, and biological facts with their optimistic tone as well as validating and explanatory functions, making life liveable. Myths project man, as it were, into another world, beyond the temporal, profane condition, into the realm of the sacred. In this way, an individual is enabled to approach a reality that is otherwise inaccessible at the level of profane individual existence (Eliade 1961: 59).

\section{Ritual}

Ritual is religion in action (Zuesse 1987: 405-422). It can be defined as "repeatable patterns of behaviour that carry complex meanings, especially when shared within a group and related to basic themes of group culture". Ritual is a formalized set of gestures or action assiduously repeated in customary order, especially the prescribed order of a religious rite (Calhoun 2002; Platzner \& Harris 2004). It can also be said that ritual is non-instinctive predictable action or a series of actions distinct from rational means-to-ends type of behaviour (Leach 1968: 520-526). That is to say, the means-to-ends relationship of ritual, to its referent, is neither intrinsic nor necessary (Penner 1981: 865-866). Ritual 
is a planned or improvised performance that effects a transition from everyday life to an alternative framework within which every day is transformed (Alexander 1994). By way of using symbolic actions, ritual communicates a forming, or transforming, message, in a unique social space outside normal life (Schirch 2005); ritual is a mode of communication (Haar 2005: 163ff), integrating our thoughts and their action (Bell 1992). In a ritual, the world, as lived and the world as imagined, fused under the agency of a single set of symbolic forms (Geertz 1973).

Ritual has been classified differently by different scholars. According to Mariasusai Dhavamony (1973), there are four types of rituals: magical, religious, constitutive and factitive. Evan M. Zuesse (1987: 405ff) divides rituals into 'confirmatory rituals' and 'transformatory rituals' with a purpose of structure maintenance. Hans Penner (1981: 865-866) classifies rituals into imitative, patterned after myths; positive, used for renewing an object or an individual; negative, connected with taboo; sacrificial, destruction of the victim, either partly or totally, and life crisis ritual dealing with transition from one mode of life to another. Among the various rituals sacrificial and life crisis rituals are of paramount importance to the life of the community as well as that of the individual. They play a vital role in moulding their worldview.

\section{Sacrifice}

Sacrifice is a religious act, which, through the consecration of a victim, modifies the condition of moral person who accomplishes the deed, or that of certain objects with which he is concerned (Hubert \& Mauss 1964).

In sacrifice, a devotee makes an offering of self to the deity by means of a gift, so as to effect the closet communication and interaction between him/her and the deity through sharing and participation in the consecrated offering.

The gift aspect of the sacrifice implies reciprocity. It involves a contract: I give that you may give. The devotee expects a favour in return. The sacrificial victim is valuable to the one who receives the sacrifice offered, and hence abnegation is an essential quality of sacrifice. For this reason, a game animal is not acceptable; the best of their domestic animals is to be chosen as the victim (Firth 1972: 325-326). There are fourteen different ideas present in sacrifice: communication, gift, apostrophic rite, bargain, exchange, ransom, elimination, expulsion, purification, expiation, propitiation, substitution, abnegation, and homage (Evans-Pritchard 1956).

Sacrifice plays an important role in religion because it displays a mode of communication between the human and deity. 


\section{Festivals}

Festivals are such privileged sacred times when a man enters the 'sacred realm' from the 'profane realm'. Man lives for the most part in a profane realm. But, at regular intervals, he seeks to enter the sacred realm, distinct from the profane realm of his every day existence, and festivals give him an opportunity to do so.

It can be said that the festivals are the major events created by an entire community, in a symbolic and active form, to show the essential life of that community (Turner 1996: 484-487). Through participation in the rituals during a festival, the devotee identifies himself/herself with the sacred time. During festivals people try to commemorate, ritually celebrate, re-enact or anticipate events or seasons that give meaning and cohesiveness to the individual and the community. This cohesiveness, brought about by festivals, can be multifarious; meeting socio-political, economic, psychological and religious needs (Fredericksen 1981: 197-202). Festivals are occasions for the display of generosity. Festival ceremonies often call for offerings of food and exchange of gifts. Redistribution of material goods in this way serves as an important economic function and brings about equality (Benet 1980). Social and cultural activities connected with festivals - songs, dances, making of costumes, cooking etc., help to enhance and preserve their cultural heritage.

The theme and the contents of festivals reflect the philosophy of life, the attitude and the likes and the dislikes of the people. Another important theme of the festivals is the propitiation of the deities and spirits, to prevent diseases, to ensure the success and the well-being of the members of the family, clan or tribe. These festivals have the power to bind the members of the community together (Lyngdoh 1991: 146ff).

\section{BHIL: AN INTRODUCTION}

The Bhil are the third largest tribal group in India, their habitat bordering four Indian states - Rajasthan, Gujarat, Maharashtra, and Madhya Pradesh (Shukla 1986). Until the 19th century, the people of the Bhil tribe were practising shifting cultivation but with the advent of British rule in India, they were compelled to settle down (Ghurye 1963). Now the Bhil have completely become cultivators. Their main occupation involves raising cereal crops, fruits and Mahua (Bassia latifolia) trees. They also rear live-stock. 
Over the years, the people of the Bhil tribe were influenced by the Rajputs (a higher Hindu caste), the Muslims and others, and have accepted many of their gods and goddesses. Yet they have been able to retain the bulk of their customary ways of living and preserve some of their own rituals associated with themselves (Mann 1978; Chaudhary et al. 1978; Nath 1960; Vidyarthi \& Rai 1985; Tod 1920).

\section{BHIL AND RELIGIOUS BELIEF}

In Bhil communities we find that their religious beliefs are closely related to things economically important to them. The lands, on which they cultivate plants, and the animals they procure, are sacred for them. For everything, whether it is land (Jamin Mata or Mother Earth), or cow or Mahua tree, there are separate myths related to each one of them and there are separate rituals in their honour. Being an agricultural tribe they worship the god connected in one way or another with fertility.

One of the main festivals of the Hindus, the festival of light Diwali is associated with the worship of sources of wealth. The Bhil people also celebrate this festival, however, with their own rituals, which are totally different from that of the Hindus' celebration. Everything associated with economy is sacred for them. In their present system of economy cattle provide a number of resources that could not easily be procured otherwise, such as the cows producing oxen, the only resource for ploughing the fields. Their poor economic condition does not permit them to buy tractors, although they are aware about the usefulness of machinery. In India, cattle wander around and are accustomed to free grazing. Thus, the Bhil tribesmen are able to feed their cattle at no cost, or little cost, to their economy. The cow dung cakes are used as cooking fuel. Alternative sources of fuel, such as wood, are scarce and costly. They cannot afford LPG fuel and cannot imagine a microwave oven. In addition, dung is also used as manure which is essential to yield three harvests a year from intensively cultivated lands. The hides and horns of cattle are used in leather industries. Above all, they drink and sell milk and the Bhil tribesmen naturally recognise their herds as the means of life.

Animals are divinities partly by birth, partly because they are forms of demonic or divine powers, and partly because they are the life-givers to many communities (Hopkins 1986). The divinity of the cows rests on that class of animals which provides a livelihood. 
In India, we find that the cow is considered sacred not only for the Bhil tribesmen but also for the members of the dominant culture, as well as for other tribes, because of the same reasons, and all have the same respect for the animals. Marvin Harris has commented that the Hindus' use of cows may have beneficial consequences that some other use of cows would not have (Harris 1966). The Hindu cow-related mythology is different from the belief of the people of the Bhil tribe. The day after Diwali they, too, celebrate the festival of cow worship. This festival is called as Gowardhan Puja. In this festival, people just decorate their cattle and worship them. They also worship the god, Krishna, who is supposed to care for the welfare of cattle. The myth behind this festival is different from the myth of Gai-Goheri.

The festival of Gai-Goheri, which is celebrated only in the Bhil dominated villages, is unique in respect of its performance. It may look bizarrely exotic for a developed society, where science has taken deep root in every walk of life, but it gives psychological satisfaction of security to Bhil tribesmen.

Due to the belief that it is their god, who helps them to have or increase their wealth, the people of the Bhil tribe remain always ready to do anything to please their supernatural deity. Different kinds of religious rituals are used to manipulate and control supernatural powers: prayers, offerings and sacrifices, telling and acting out of myths, music, and altering emotional states through physical sufferings or drugs (Nanda 1987).

The festival of Gai-Goheri uses a combination of all the practices to control supernatural power.

Similar to any other society, the remembrance of some past events is the basis of common celebration in the Bhil community. The mythical elements of the festival always form an important part of the ritual process and the ritual always commemorates something related to myth. The people of the Bhil tribe get sanction from their myths and these myths and legends explain and guide the people to observe the festivals in the memory or respect of the said hero or event. The mythological sanctions are well reflected in their dances, songs, and sacred performances. Participants in religious ceremonies may bring a sense of personal transcendence, a waning of fear, security, and even ecstasy, or a feeling of closeness of fellow participants. Gai-Goheri reduces the anxiety and uncertainty to which the people of the Bhil tribe are subject to in terms of the welfare of their cattle and how they can increase their herd. In this article, an attempt has been made to discuss three basic things that most vividly characterize the festival of the Gai-Goheri-myths, rituals, and beliefs. 


\section{THE FESTIVAL: THE RITUAL}

The festival of Gai-Goheri is a part of Diwali celebrations. The actual celebration begins one day before Diwali, reaching a climax on the next day of Diwali.

On the day of Choudas, fourteenth day of Kartik (October-November), the Bhil tribesmen, taking a heated iron rod filled with mud, burn the buttocks of their cattle. They believe that doing so will prevent any sickness of the cattle. They believe that an evil eye causes sickness, yet evil eyes do not do any harm to physically suffering animals. Seldom do they seek veterinary assistance.

In the afternoon, they take their animals to a nearby stream, tank or river and give them a good washing.

In the morning of Diwali, after sunrise, the Bhil people indulge in the decoration of cattle, using vermilion powder, mixed with oil and water, to paint the horns of cows, bullocks and buffaloes. Using different colours they decorate the body of their cattle by painting, rings, flowers etc. Peacock feathers, artificial flowers, etc. are fastened to their heads. They also position women's hairbands round the heads of cows to give magic protection to them. The cattle are fed with maize and lentils cooked together, showing their love and emotions towards their animals.

The day after Diwali, Bhil men worship the cow, and other cattle, by sprinkling water and rice on them. They put kumkum (red powder) marks on the head of the cattle. All the villagers make their cattle gather at a central place after forcing them to tour around the village. Others follow them dancing and singing, thus creating a festive mood.

Meanwhile on the path, over which the cattle are supposed to pass finally, the tadvi (village chief) sacrifices a cockerel, spreading the blood on the path. They believe that by doing so they are safeguarding their cattle from diseases and protecting the worshipper from harm. When all the cattle gather at one place, they are forced to run in a group, by the exploding firecrackers, the shouting and beating of the thali (bronze plate) with sticks. The animals are forced to pass under a toran (a string decorated with coloured papers and mango leaves). This toran stays fixed with the help of two bamboos poles erected parallel on each side of the path. In the middle of the toran the villagers have tiered clothes and a bronze plate, with some mantras (sacred spell) written thereon. They are not able to tell the meaning of the mantras. They believe that by passing under the toran, all diseases would leave the cattle. Near the bamboo, they light a diya (oil lamp) and some incense sticks. Dhup (perfumed saw dust) is also consumed on burning coals kept in a kabelu (censer). At first a she-calf is allowed to pass under the toran then other cattle are forced to 
follow her. A few yards after the toran place the young men (participants) stand and other villagers congregate along one side.

Covering their eyes with their crossed arms, the participants prostrate themselves before the running cattle with the animals stepping over them. Some of them repeat the prostrating three to four times and get themselves seriously injured. After this some people, present there watching the whole celebration, make them stand. Participants inhale the smoke of dhup. In this way, they make themselves free from the ecstatic trances under the influence of which they underwent the ceremonial torture, thereby to please their god. Their family members sing and dance to the beat of drums. One of the family members keeps one egg and some milk commemorating the Wasing Cobra (SnakeGod) near the jhapa (entrance gate) of the home. Later on, they keep that egg and milk near any anthill - as the people of the Bhil tribe believe that snakes live therein.

After the celebration, men present sacrifice goats and cockerels and cook them, while women prepare roti (breads) and cook rice. This shows a good division of labour and after having a good meal they all return home in a jubilant mood, free from anxiety regarding the future and uncertainty regarding the safety of their cattle, their vital subsistence.

\section{MYTH}

Dharmi Raja, the well wisher of cattle, is the son of Baba Dev and Kalka Rani. When Dharmi Raja reached the age of puberty, his parents called a Brahmin to find a bride for the son. The Brahmin selected Dholka Rani for Ddharmi Raja.

After marriage, as a custom, bride's parents offered food to the newly wed couple. They refused to take food and asked for a cow named Rupan. The bride's parents presented Rupan cow to them. After having their meal, Dharmi Raja started his return journey home with his wife and the cow. On the way, Dharmi Raja came to know that the cow, named Rupan was not physically fit. She was a lame cow. He became angry and scolded his wife for accepting the lame cow. He refused to take that lame cow with him and said to his wife if she wanted to take the cow there was no need to follow him. Helpless Dholka Rani was looking here and there and thinking what to do. She saw an anthill where Wasing Cobra (Snake God) was lying. She asked the Cobra what to do with that lame cow. Wasing Cobra advised her to pour a few drops of blood on a stone. After cutting the little finger of her right hand, she poured a few drops of blood 
on a stone. Suddenly the stone, on which the blood was poured, turned to one side and a big ditch was created. Dholka Rani, after pushing that lame cow into the ditch, followed her husband.

One night Dharmi Raja dreamt that someone was telling him to pour some blood from the little finger of his right hand on the same place and stone which Dholka Rani had doused earlier. He was told that by doing so he would get twelve hundred cattle. Dharmi Raja had to lead the cattle holding a red flag. Furthermore, he was warned by that man not to look back.

When Dharmi Raja followed his dream, cattle started coming out one by one from that ditch. Dharmi Raja started running fast leading these cattle. In this process, some of the cattle stomped on the body of Dharmi Raja, thus hurting him badly. In agony he wanted to know how many cattle were still coming, hence he looked back. The flow of the cattle coming out of that ditch stopped but Dharmi Raja found one bull left in the ditch.

Thus, it is believed by the Bhil tribesmen that owing to that very act, the number of bulls is less than cows, even today.

\section{Analysis of the myth}

By examining the myth more closely, in order to show some of the basic value embodied in the tale, we find:

1. It is a father's responsibility to select a bride for his son. In the society of the Bhil, young people have the freedom to select life partners of their own choice. However, shouldering the responsibility of selecting a bride for their son is equally common among the parents of the tribe. For selecting the girl the father of the son sends an intermediary known as a bhanzgerio, and not a Brahmin. How and when a Brahmin actually appeared in their mythological story the Bhil people are yet to explain.

2. Dharmi Raja ordered his wife not to follow him and threatened to abandon her in the forest. This speaks of the helplessness of a bride if she would not always obey her husband.

3. Dholka Rani might have known about the super power of the Rupan cow, because both of them were living in the same house, yet she was not able to convince her husband and became ready to leave the cow only for the sake of the happiness of Dharmi Raja. This shows wifely devotion and respect for the tradition. 
4. In Bhil society, the bride's father takes the bride's dowry and gives anything of his own choice to the couple. There is no provision for the groom to ask for any gifts. Here Dharmi Raja makes demands for a gift. This shows the influence of a dominant culture where the dowry system is prevalent, in their mythological story.

5. If the gift does not satisfy the husband, he can abandon his wife. He takes revenge on his wife and not on the in-laws who present the gift. This again shows the helplessness of a wife.

6. Dharmi Raja, who is responsible for the welfare of cattle, banished a cow, a sacred one in the Bhil society, only because she was lame. Why did he do so? The Bhil people are not able to answer. May be only after this incidence (receiving numerous cattle from a lame cow), he became the well-wisher of the cattle, Bhil tribesmen suggest.

7. Why did the cow, neglected by Dharmi Raja, provide so many cattle for him? May be to give a lesson to him not to neglect any cow, because even a lame cow can produce so many young cattle or create wealth. May be to please Dharmi Raja for the welfare of Dholka Rani. After all, both of them were reared in the same house. May be to show her power to Dharmi Raja. The above are the thoughts of the Bhil people.

8. How can a cow remain alive in a ditch and produce so many cattle? Bhil people believe God is almighty and performs miracles.

9. Why no punishment for Dharmi Raja for his cruel behaviour, instead he receives a reward - the Bhil tribesmen are not able to explain.

10. As usual, a happy ending to make the myth acceptable.

Despite many 'whys' and 'hows' Bhil people do believe in this story and celebrate 'Gai-Goheri' with full faith as well as devotion. Their fore-fathers had also celebrated this festival with full devotion, and so a young Bhil would start thinking of celebrating this festival at a very early age. Thus, the sacred values, once sanctioned and established by their society, are not challenged by newer ideas; rather they are followed for the sake of happiness throughout life.

\section{SUMMARY AND CONCLUSION}

Cattle play a very important role in the present economic life of the Bhil tribe; therefore the tribesmen remain ready to do anything necessary for the welfare of their herd. 
To please the 'god of cattle', the tribesmen celebrate the festival of ceremonial torture Gai-Goheri. In this festival, they use different rituals such as prayers, offerings and sacrifices, telling and acting out of myths, and go for physical torture.

Gai-Goheri is a good example of a festival showing how myths and beliefs give rise to the series of rituals, the celebration of which is not only a source of entertainment, but would also assist them in reducing the anxiety and uncertainty related to the welfare of their cattle and in increasing the number of their animals. This festival makes their life happy and simultaneously enables them to get rid of any stress and strain.

\section{REFERENCES}

Alexander, Bobby Chris 1994. Televangelism Reconsidered: Ritual in the Search of Human Community. Atlanta: Scholar Press.

Bell, Catherine 1992. Ritual Theory: Ritual Practice. New York: Oxford University Press.

Belmont, Nicole 1996. Myth. In: A. Kuper \& J. Kuper (eds.) The Social Science Encyclopedia: London: Routledge, pp. 308-309.

Bolle, Kees W. 1981. Myth and Mythology. The New Encyclopaedia Britannica. Chicago: Encyclopaedia Britannica, pp. 797-800.

Calhoun, Craig 2002. In: C. Calhoun (ed.) Dictionary of the Social Sciences. New York: Oxford University Press.

Chaudhary, N. D. \& Vyas, N. N. \& Mann, R. S. (eds.) 1978. Rajasthan Bhils. Udaipur: Tribal Research Institute.

Dhavamony, Mariasusai 1973. Phenomenology of Religion. Rome: Gregorian University Press.

Dumézil, Georges 1970. The Destiny of the Warrior. Chicago. University of Chicago Press.

Eliade, Mircea 1961. Images and Symbols: Studies in Religious Symbolism. London: Harvill Press, p. 59.

Evans-Pritchard, Edward Evan 1956. Nuer Religion. Oxford: Clarendon Press.

Firth, Raymond W. 1972 Offerings and Sacrifice: Problems of Organization. In: W. A. Lessa \& E. Z. Vogt (eds.) Reader in Comparative Religion. New York: Harper \& Row, pp. 325-326.

Fredericksen, Linwood 1981. Feast and Festival. The New Encyclopaedia Britannica Chicago: Encyclopaedia Britannica, pp. 197-202.

Geertz, Clifford James 1973. The Interpretation of Cultures: Selected Essay. New York: Basic Books.

Ghurye, Govind Sadashiv 1963. The Scheduled Tribes. Bombay: Popular Prakashan. Graeve, Filip de et al. 2002. Myth, Literary. New Catholic Encyclopedia. Washington: Thomson/Gale, pp. 120-125. 
Haar, Gerrie ter 2005. Ritual as Communication: A Study of American Christian Communities in the Bijlmer District of Amsterdam. In: G. Harvey (ed.) Ritual and Religious Belief: a reader, pp. 163-185: London: Equniox.

Harris, Marvin 1966. The Cultural Ecology of India's Sacred Cattle, Current Anthropology, Vol.7, No. 1.

Harrison, Jane Ellen 1963. Mythology, New York: Cooper Square Publishers.

Hopkins, Edward Washburn 1986. Epic Mythology. Columbia, MO: South Asia Books.

Hubert, Henri \& Mauss, Marcel 1964. Sacrifice: Its Nature and Function. London: University of Chicago Press.

Kirk, Geoffrey S. 1970. Myth: Its Meaning and Functions in Ancient and Other Cultures. Cambridge: Cambridge University Press.

Leach, Edmund R. 1968. Ritual. In: D. L. Sill et al. (eds.) International Encyclopedia of Social Sciences. New York: MacMillan, pp. 520-526.

Lyngdoh, Mary Pristilla Rina 1991. The Festivals in the History and Culture of the Khasi. New Delhi: Har-Anand Publications/Vikas Pub. House in New Delhi, pp. 146-171.

Malinowski, Bronislaw 1954. Magic, Science and Religion and Other Essays. New York: Doubleday.

Mann, R. S. 1978. Religious Attributes of Bhils. In: N. N. Vyas; R. S. Mann \& N. D. Chaudhary (eds.) Rajasthan Bhils: Udaipur: Tribal Research Institute.

Mercatante, Anthony S. 1988. Myth. In: A. S. Mercatante (ed.) The Facts on File Encyclopedia of World Mythology and Legend. New York: Facts on File.

Nanda, Serena 1987. Cultural Anthropology. Belmont, CA: Wadsworth Publishing Company.

Nath, Y.V.S. 1960. Bhils of Ratanmal:An Analysis of Western India Community. Baroda: Maharajah Sayajirao University.

Penner, Hans H. 1981. Rituals. The New Encyclopedia Britannica. Chicago: Encyclopaedia Britannica, pp. 865-866.

Platzner, Gloria \& Harris, Stephen L. 2004. Classical Mythology: Images and Insights New York: McGraw Hill.

Roberts, Keith A. 1984. Religion in Sociological Perspective. Homewood, Ill: Dorsey Press.

Rosenberg, Donna 1999 World Mythology: An Anthology of the Great Myths and Epics. 3rd ed. NTC Publishing Group.

Schirch, Lisa 2005. Ritual and Symbol in Peacebuilding. Bloomfield: Kumarian Press Inc.

Shukla, Hira Lal 1986. Tribal Heritage of Madhya Pradesh. New Delhi: B. R. Publishing Corporation.

Sløk, Johannes 2003. Myth and Mythology. New Catholic Encyclopedia. Washington: Thomson Gale, pp. 124-129.

Tod, James 1920. Annals and Antiquities of Rajasthan. London: Routledge and Kegan.

Turner, Edith 1996. Feast and Festivals. In: D. Levinson \& M. Ember (eds.) Encyclopedia of Cultural Anthropology. New York: Henry Holt \& Company, pp. 484-487. 
Vidyarthi, Lalita Prasad \& Rai, Binay Kumar 1985. The Tribal culture of India. New Delhi: Concept Publishing Company.

Zuesse, Evan M. 1987. Ritual. In: M. Eliade (ed.) The Encyclopedia of Religion. New York: MacMillan Publishing Company, New York, pp. 405-422. 